\title{
ONTOLOGY FOR FACEBOOK IN RELATION TO IBN KHALDUN ETHICS: A SYSTEMATIC REVIEW
}

\author{
Mohamad Hafizuddin Mohamed Najid \\ Department of Library and Information Science, International Islamic University Malaysia; \\ hafizuddinajid@gmail.com \\ Zahidah Zulkifli \\ Department of Information Systems, International Islamic University Malaysia; \\ zahidahz@,iium.edu.my \\ Roslina Othman \\ Department of Library and Information Science, International Islamic University Malaysia; \\ roslina@iium.edu.my
}

\begin{abstract}
Social networking sites (SNS) especially Facebook become a popular platform for sharing and communicate with people all around the world. Its popularity is rising together with the ethical issues that need to be faced by normal users. Since these issues have gotten the people intention, the aim of this paper is to provide an overview of the ontology of Facebook in relation to Ibn Khaldun ethics. A systematic literature review of the articles been conduct related with ontology in Facebook and Ibn Khaldun thoughts which met the following selection criteria: (1) published in a peer-reviewed journal, (2) written in English, (3) free accessed download article, (4) range date from 2008 to 2017, (5) article content related to search topic. The literature search generated 172,731 records of article searched from selected 4 databases from IIUM library website and only 2,235 article titles or abstracts have been screened, which match with author's keywords. After refined the results, 84 abstract and full-text articles were retrieved and reviewed. The findings identify types of articles by classes in eight categories, namely: (1) author name, (2) year of publication, (3) research methodology being used, (4) retrieved from which database, (5) the area covered by the article, (6) journal name, (7) journal ranking by Scopus, (8) journal subject. In conclusion, the contribution of ontology development between Ibn Khaldun's thoughts may relate to ethical issues on Facebook, and thus will be a guideline for others researcher to review a model for developing ontology concepts for ethics to extend to broader areas.
\end{abstract}

Keywords: Ontology, Facebook, Social Networking Sites, Ibn Khaldun, Ethics

\section{Introduction}

The emergence of information and communication technology (ICT) has changed how people communicate with each other. Since the introduction of social networking sites (SNS) such as Myspace, Facebook, and Twitter have attracted millions of users around the world. Many of people have integrated these sites into their daily routine activities to socially interact with one another [1][2]. The use of SNS is not only a mere trend but has become part of every person's life [3][4]. This trend nowadays has lead researchers to conduct studies on SNS in relation to user behavior.

According to Alexa.com [19] and Ranking.com [20], a website that tracks web traffic, the top 10 websites on the Internet include search engines and online collaboration tools showed that SNS such Facebook ranks third places for the most popular websites visited. The Facebook's users are an interesting population for research to study their public linkages, individuals profile and their real identity also their connection to a community [5]. Ethics have become a big issue in the ICT world because ethical or not ethical is dependent on changing technology and people's attitude [6]. The explosion of SNS has changed the way human beings connect, collaborate and live their daily lives [7].

Social media research is considered to consist of investigations of user behavior on almost all platforms display user contributions or user activities [8]. The related issues are about cyberbullying on SNS goes beyond boundaries of time and space [9]. According to the cyberbullying research center 
website, approximately $34 \%$ of the students experiencing cyberbullying in their lifetimes [21]. Highlighting SNS as a social platform for people to communicate with other people, Ibn Khaldun's thoughts contributed significantly to the understanding of human culture and civilization [18]. Having considered the issues of human sociology, he has contributed to the advancement of human civilization and the currents of history [10]. Some of his ideas can suit contemporary needs yet others are only applicable in a prolonged history of civilizations [17]. The discipline of social science has evolved similarly to Ibn Khaldun's thinking and approaches which suited our changing times [11]. His masterpiece al-Muqaddimah book still has been the topic of discussion among researcher and scholars until nowadays.

The main purpose of this study was to conduct a systematic review of the literature on the ontology for Facebook in relation to Ibn Khaldun ethics. This paper would highlight an extensive literature review from selected databases subscribe by International Islamic University Malaysia (IIUM) Library, to pool finding from different studies, to find expertise in the topic area and to update recent studies on the topic. In recent years, the ontology provides a mechanism to capture ideas, concepts, and relationships and describe a logical domain theory with very expressive, complex and meaningful information [12]. Ontologies have become an increasingly important research topic [13]. It provides a

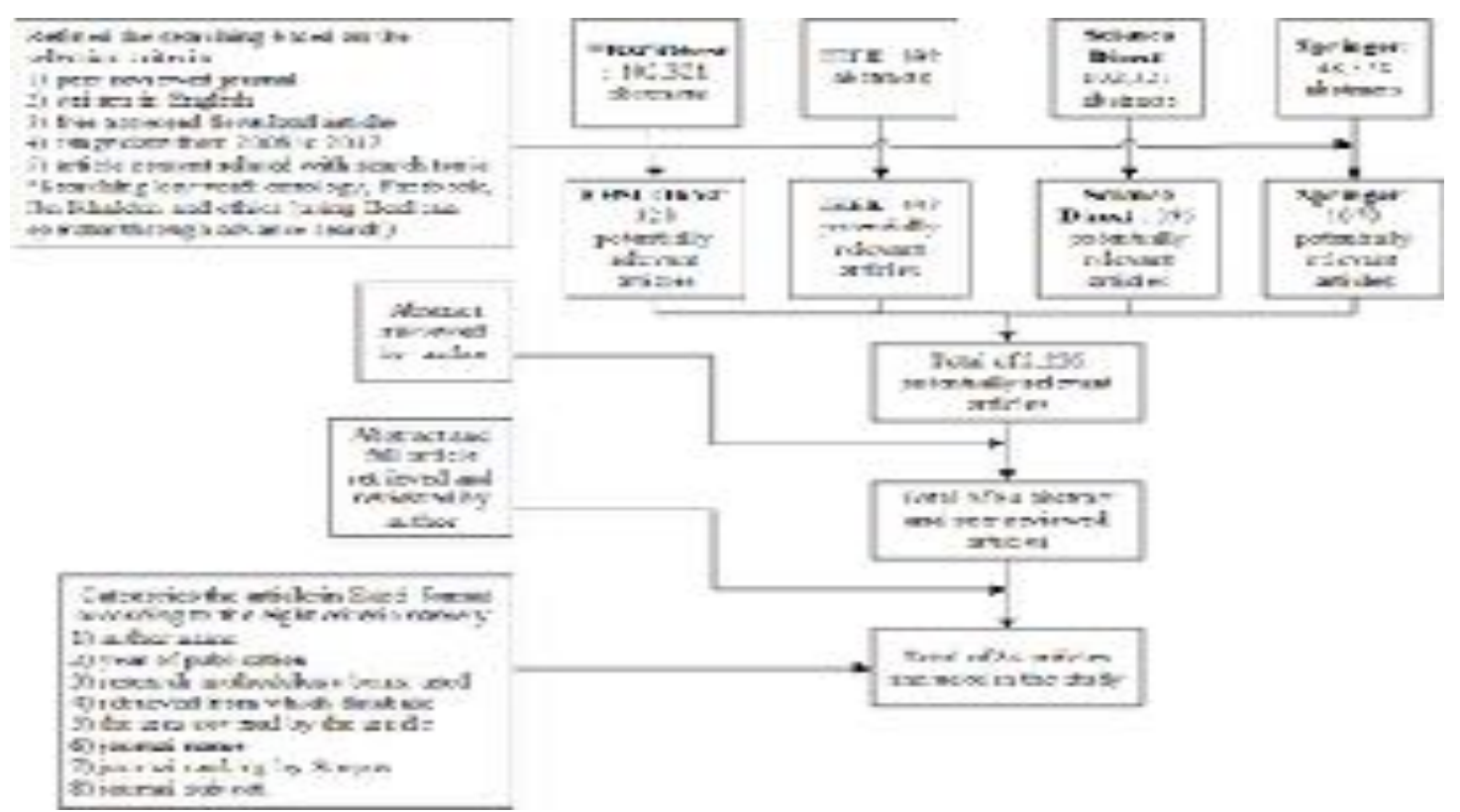

Figure 1: Methodology Diagram for Article Selection

representation of a shared conceptualization of a particular domain that can be communicated to people and applications. Ontology is the main topic of this paper due to the mechanism to manage information about the ideas, concepts and the relationships between different domains because the knowledge applied have different characteristics. Applying an ontology tools is a help to assemble information and to organize them properly.

\section{Method}

\section{Data Sources}

To conduct the search, firstly the author goes through by review 42 online databases subscribed by IIUM Library database in the different subject from their website. Next, the author select 9 databases related to ICT only. The selected databases are EBSCOhost (Academic Search Premier), EBSCOhost (Business Source Complete), Classification Web, IEEE Explore, Index Islamicus, Science Direct, Springer Link, Taylor and Francis Online and Web of Science TM. Lastly, the author reviewed the listed databases subject content and from that only 4 relevant databases were selected and they are EBSCOhost, IEEE Explore, Science Direct and Springer Link.

\section{Selection Criteria}

The author select and searched the articles through these 4 databases by retrieved and reviewed the abstract and article which are meet following selection criteria as follows: (1) published in a peer- 
reviewed journal, (2) written in English, (3) free accessed download articles, (4) range date from 2008 to 2017, (5) article content related to search topic. To identify the articles, we employed searching process use connectors to search for more than one word in a single search by using Boolean operator (e.g. OR, AND, and AND NOT) through advanced search tool by mix and match of the keyword: ontology, Facebook, Ibn Khaldun and ethics (Table 1).

\section{Data Analysis}

After the retrieving and reviewing process of the abstracts, the article's findings were further categorized according to 8 categories in the Microsoft Excel. The findings of each article were categorized by screening the data and information available in the articles. From this, the author can look and view the data formatted in Microsoft Excel and make a comparison with other articles. It's also helped us to view and differentiate the data from all the articles and categorize them. By analyzing the articles result in this way, the author can formulate the discussion section. To write up this article, the author followed the guidelines in conducting a systematic literature review as prescribed by the Preferred Reporting Items for Systematic Literature Reviews and Meta-Analyses (PRISMA) [14] and also other article did under this theme from [15] and [16].

\section{Results}

The searches generated 172,731 records total number from 4 selected databases. Only 2,235 article titles or abstracts were screened, which match with selected author keyword. If criteria were not met due to insufficient information, the title or abstract will be skipped. After refinement, the remaining 84 abstract and full-text articles were retrieved and reviewed been included in this study based on the selection criteria (Figure 1). The list of the reviewed article was categories in Microsoft Excel since the study involves counting and tabulating data. The reviewed article has been tabulated in the form of a table according to the 8 categories namely: (1) author name, (2) year of publication, (3) research methodology being used, (4) retrieved from which database, (5) the area covered by the article, (6) journal name, (7) journal ranking by Scopus, (8) journal subject.

Table 1: Mix-and-match of the keyword used in searching process

\begin{tabular}{|l|l|l|l|}
\hline DATABASE & KEYWORD & RESULT & TOTAL \\
\hline EBSCOhost & Facebook & 102,201 & $/$ \\
\hline & Facebook + Ethics & 835 & \\
\hline $\begin{array}{l}* \text { Facebook + Ethics (Full } \\
\text { text) }\end{array}$ & 310 & \\
\hline *Ontology + Facebook & 8 & \\
\hline & $\begin{array}{l}\text { Ontology + Facebook } \\
\text { Ethics }\end{array}$ & 0 & $/$ \\
\hline Ibn Khaldun & 120 & \\
\hline *Ibn Khaldun + Ethics & 5 & 102,321 \\
\hline Ontology + Ibn Khaldun & 0 & $/$ \\
\hline IEEE & *Facebook & 391 & \\
\hline Facebook + Ethics & 9 & \\
\hline & *Ontology + Facebook & 55 & \\
\hline & $\begin{array}{l}\text { Ontology + Facebook } \\
\text { Ethics }\end{array}$ & 0 & \\
\hline & *Ibn Khaldun & 1 & \\
\hline Ibn Khaldun + Ethics & 0 & \\
\hline
\end{tabular}


The Turkish Online Journal of Design, Art and Communication - TOJDAC

ISSN: 2146-5193, September 2018 Special Edition, p.1107-1114

\begin{tabular}{|c|c|c|c|}
\hline & Ontology + Ibn Khaldun & 0 & 392 \\
\hline \multirow[t]{7}{*}{ Science Direct } & Facebook & 21,465 & 1 \\
\hline & $*$ Facebook + Ethics & 270 & \\
\hline & $\begin{array}{l}* \text { Ontology }+ \text { Facebook (Full } \\
\text { text) }\end{array}$ & 86 & \\
\hline & Ibn Khaldun & 225 & / \\
\hline & *Ibn Khaldun (Full text) & 21 & \\
\hline & *Ibn Khaldun + Ethics & 7 & \\
\hline & *Ontology + Ibn Khaldun & 11 & 21,690 \\
\hline \multirow[t]{8}{*}{ Springer } & Facebook & 48,318 & 1 \\
\hline & $\begin{array}{l}\text { Facebook (Full text \& } \\
\text { English language) }\end{array}$ & 2,705 & \\
\hline & *Facebook + Ethics & 990 & \\
\hline & $*$ Ontology + Facebook & 43 & \\
\hline & $\begin{array}{l}* \text { Ontology }+ \text { Facebook }+ \\
\text { Ethics }\end{array}$ & 24 & \\
\hline & *Ibn Khaldun & 10 & / \\
\hline & Ontology + Ibn Khaldun & 0 & \\
\hline & *Ibn Khaldun + Ethics & 3 & 48,328 \\
\hline \multicolumn{3}{|c|}{$\begin{array}{l}+ \text { symbols }=\text { AND } \\
* \text { Reviewed the article abstract by using this keyword }\end{array}$} & $\begin{array}{l}172,731 \\
\text { TOTAL ALL }\end{array}$ \\
\hline
\end{tabular}

\section{Discussion}

The author retrieved and reviewed 84 abstract and full-text of articles and tabulated the data by categories in Microsoft Excel. From our overview, after extracted the findings regarding the types of authorship pattern, the results showed that 22 papers were written by the single author, 25 papers produced by two authors and the balance paper total 37 have produced by three authors and above (Table 2). All of the author's names are not repeated with each other from the article title list and it means the author produced one article only. View from the articles published by the year, most of the papers are published in the year 2013 with 17 papers, followed by 14 papers published in 2017, in the year 2015 around 13 papers published and lastly 11 papers published in 2016. For the balance years range from 2014 until 2009, the total paper published is below than 10 (Table 3).

In the topic area view, Social Network or Social Media topic is mostly covered in the article has been reviewed with 29 titles followed by topic on Facebook with 22 titles, Ontology topic area with 16 titles and Ibn Khaldun's topic with 7 titles (Table 4). From the journal name published the article, it's showed that the Journal Procedia Social and Behavioral Sciences was the highest with 18 titles, next from a variety of conference paper journal with 12 titles. The following ranks were Journal of Business Ethics with 5 titles and lastly article from Computers in Human Behavior journal with 4 titles (Table 5). For the journal subject area, the author search the ranking through Scopus website [22] and find out that the highest subject area covered by the articles was Psychology with total 20, next 19 subject area is covered by Social Sciences, followed by Computer Science subject with total 7, 5 subject from Medicine, lastly Arts and Humanities: Arts and Humanities (miscellaneous) subject with total 4. The balance 25 of the journal is not listed in the rank and some of the journal coverage is discontinued by Scopus website from the selected years (Table 6).

Table 2: Authorship pattern from article reviewed 
The Turkish Online Journal of Design, Art and Communication - TOJDAC

ISSN: 2146-5193, September 2018 Special Edition, p.1107-1114

\begin{tabular}{|c|c|}
\hline Authors number & Total \\
\hline Single & 22 \\
\hline Two & 25 \\
\hline Three and above & 37 \\
\hline
\end{tabular}

Table 3: Article published by year

\begin{tabular}{|l|l|}
\hline Year & Total \\
\hline 2009 & 3 \\
\hline 2010 & 3 \\
\hline 2011 & 8 \\
\hline 2012 & 5 \\
\hline 2013 & 17 \\
\hline 2014 & 10 \\
\hline 2015 & 13 \\
\hline 2016 & 11 \\
\hline 2017 & 14 \\
\hline
\end{tabular}

Table 4: Topic area covered by article

\begin{tabular}{|c|c|}
\hline Topic Area & Total \\
\hline Social Network or Social Media & 29 \\
\hline Facebook & 22 \\
\hline Ontology & 16 \\
\hline Ibn Khaldun & 7 \\
\hline Information Technology (IT) & 5 \\
\hline Cybercrimes or cyberbullying & 3 \\
\hline Semantic or Social Contract & 2 \\
\hline
\end{tabular}

Table 5: Journal name published the article

\begin{tabular}{|c|c|}
\hline Journal Name & Total \\
\hline Journal Procedia Social and Behavioral Sciences & 18 \\
\hline Conference paper journal & 12 \\
\hline Journal of Business Ethics & 5 \\
\hline Computers in Human Behavior & 4 \\
\hline
\end{tabular}

Submit Date: 10.07.2018, Acceptance Date: 22.08.2018, DOI NO: 10.7456/1080SSE/151

Research Article - This article was checked by Turnitin

Copyright $\mathbb{C}$ The Turkish Online Journal of Design, Art and Communication 
The Turkish Online Journal of Design, Art and Communication - TOJDAC

ISSN: 2146-5193, September 2018 Special Edition, p.1107-1114

\begin{tabular}{|l|l|}
\hline \multicolumn{1}{|c|}{ Procedia Computer Science } & 3 \\
\hline International Journal of Educational Technology in Higher Education & 2 \\
\hline
\end{tabular}

Table 6: Journal subject area

\begin{tabular}{|c|c|}
\hline Subject Area & Total \\
\hline Psychology & 20 \\
\hline Social Sciences & 19 \\
\hline Computer Science & 7 \\
\hline Medicine & 5 \\
\hline Arts and Humanities: Arts and Humanities (miscellaneous) & 4 \\
\hline Journal coverage is discontinued by Scopus & 25 \\
\hline Mathematics, Decision Science, Engineering, Economics & 4 \\
\hline
\end{tabular}

\section{Conclusion}

The findings show that the different perspectives on research trends for the literature on the ontology for Facebook in relation to Ibn Khaldun ethics. Most of the article on social media topic or Facebook highlights about privacy issues and ethical or behavior among their users. Some of the authors also mention that Facebook as learning tools referred to their functions in spreading the information to others and highly users in usage. It's can be assumed that the advanced of the social communication technology got an intention from researchers in their research area. From the authorship pattern, it also varied from a single author, two authors, three authors and more. It showed that authors in this field prefer to produce their article with collaboration with others since the result showed that 23 articles are proposing the framework and conceptual model and they need collaborative ideas or opinion to develop it.

Quantitative methodology mostly applied by the researcher in their article with total 21 , a qualitative methodology around 17 and 19 article proposed a model. The year 2013 until 2017 was the famous years for the authors produced the article. This can be assumed by the social problems raised on SNS technology developed in past year until now. Social network or social media topic area is highly covered in the most of the reviewed article with 37 titles and Journal Procedia Social and Behavioral Sciences are mostly published the article with 18 titles. The results indicate that the literature in this topic area is higher because of the social network as a platform for social communication and related to a human sociology behavior. The article mostly highlights under that journal subject area which is psychology.

Findings in this paper need to be considered with some limitations with the interesting results presented above. It is possible that we missed some articles during the searching process that could have used different terminology in the title, abstract, article objectives, and methods. Furthermore, the results of retrieved and reviewed paper might not be covered for all SNS platforms since we are focused only on Facebook. For practical reasons, the author excluded non-English papers and refined the searching in the range of the years 2008 until 2017 only. In this paper, the author highlighted the findings on the topic of been study, categorized, and analyzed the article related to ontology for Facebook in relation to Ibn Khaldun ethics. The contribution of ontology development between Ibn Khaldun's thoughts may relate to ethical issues on Facebook, and thus will be a guideline for others researcher to review a model for developing ontology concepts for ethics to extend to broader areas.

\section{References \\ Articles}

[1] D. Boyd and N. Ellison, "Social network sites: definition, history, and scholarship," IEEE Eng. Manag. Rev., 2010. 
[2] K. Li, X. Wang, K. Li, and J. Che, "Information privacy disclosure on social network sites: An empirical investigation from social exchange perspective,” Nankai Bus. Rev. Int., vol. 7, no. 3, pp. 282-300, 2016.

[3] N. S. Casado, J. G. C. Navarro, A. Wensley, and E. T. Solano, "Social networking sites as a learning tool," Learn. Organ., vol. 23, no. 1, pp. 23-42, 2016.

[4] H. Waheed, M. Anjum, M. Rehman, and A. Khawaja, "Investigation of user behavior on social networking sites," pp. 1-20, 2017.

[5] R. Gross, A. Acquisti, and H. J. H. Iii, "Information Revelation and Privacy in Online Social Networks (The Facebook case)," 2005.

[6] M. Al-A'ali, "Computer ethics for the computer professional from an Islamic point of view, " J. Information, Commun. Ethics Soc., vol. 6, no. 1, pp. 28-45, 2008.

[7] A. Acquisti and R. Gross, "Imagined Communities : Awareness, Information Sharing and Privacy on the Facebook," pp. 36-58, 2006.

[8] K. Weller, "Accepting the challenges of social media research," Online Inf. Rev., vol. 39, no. 3, pp. 281-289, 2015.

[9] M. Taylor, J. Haggerty, D. Gresty, N. Criado Pacheco, T. Berry, and P. Almond, "Investigating employee harassment via social media," J. Syst. Inf. Technol., vol. 17, no. 4, pp. 322-335, 2015.

[10] T. Azadarmaki, "An Analysis of The Roots of Ibn Khaldun's Social Theory: A Case study in Sociological Metatheorizing," 1992.

[11] Z. Abdul Rahman, "Ibn Khaldun's New Science and Its Contribution to the Social Sciences and Risk Management," pp. 1-20, 1997.

[12] F. Harrag, A. Al-Nasser, A. Al-Musnad, R. Al-Shaya, and A. S. Al-Salman, "Using association rules for ontology extraction from a Quran corpus, "5th Int. Conf. Arab. Lang. Process.2013

[13] R. S. S. Bechhofer, I. Horrocks, C. Goble, "OilEd: a Reason-able Ontology Editor for the Semantic Web," 2001.

[14] D. Moher et al., "Preferred reporting items for systematic review and meta-analysis protocols (PRISMA-P) 2015 statement," vol. 4, no. 1, pp. 1-9, 2015.

[15] E. Smailhodzic, W. Hooijsma, A. Boonstra, and D. J. Langley, "Social media use in healthcare: A systematic review of effects on patients and on their relationship with healthcare professionals," BMC Health Serv. Res., pp. 1-14, 2016.

[16] L. A. Schindler, G. J. Burkholder, O. A. Morad, and C. Marsh, "Computer-based technology and student engagement : a critical review of the literature," 2017.

\section{Books}

[17] Ahmad, B. (2009). Ibn Khaldun's legacy and its significance: proceedings International Conference. Kuala Lumpur: International Institute of Islamic Thought and Civilization (ISTAC)

[18] Osmani, N. M. \& Nurullah, A. S. (2009). Ibn Khaldun's legacy and its significance: proceedings International Conference. Kuala Lumpur: International Institute of Islamic Thought and Civilization (ISTAC)

\section{Websites}

[19] Alexa (2017) https://www.alexa.com

[20] Ranking (2017) http://www.ranking.com

[21] Cyberbullying (2016) https://cyberbullying.org

[22] Scopus https://www.scopus.com 
The Turkish Online Journal of Design, Art and Communication - TOJDAC

ISSN: 2146-5193, September 2018 Special Edition, p.1107-1114 